\title{
Does The Use of Social Network Service LINE Affect First-Year College Students' Social Adjustment?
}

\author{
Elok Dianike Malay, Aulia Nataningsih \\ Fakultas Psikologi, Universitas Indonesia, Depok, Jawa Barat - 16424
}

\begin{abstract}
This study examined the influence of social networking service (SNS) usage, especially LINE, on the first-year college students' social adjustment in Indonesia. We hypothesized that the number of LINE friends from the same university, the number of actual friends in LINE, and propensity to use LINE predicted the social adjustment of first year students. To examine the hypothesis, we surveyed 120 first-year college students. Linear regression analysis showed that LINE usage affected students' social adjustment. The number of actual friends in LINE and propensity to use LINE to collaborate with other students positively predicted social adjustment. On the other hand, the number of college friends in LINE did not contribute significantly to their social adaptation. These results give more evidence of the beneficial effect of SNS, especially LINE, on the first-year college students' social adjustment in their campus. However, it is essential to note that SNS would give a beneficial effect if students could develop a real friendship through it and use it for collaborative activities.
\end{abstract}

Keywords: college adjustment; college students; SNS use; social adjustment; social media

\begin{abstract}
Abstrak
Penelitian ini ingin membuktikan ada atau tidaknya pengaruh dari penggunaan layanan jejaring sosial (social network service) atau media sosial, khususnya LINE, terhadap penyesuaian sosial (social adjustment) mahasiswa tahun pertama di Indonesia. Hipotesis studi ini adalah jumlah teman dari kampus yang sama di LINE, jumlah teman sesungguhnya di LINE, dan kecenderungan penggunaan LINE memprediksi penyesuaian sosial. Sebanyak 120 mahasiswa tahun pertama yang menjadi partisipan penelitian ini. Hasil analisis regresi linear menunjukkan bahwa penggunaan LINE memiliki pengaruh terhadap penyesuaian sosial mahasiswa tahun pertama. Jumlah teman yang sesungguhnya di LINE serta kecenderungan untuk menggunakan LINE demi aktivitas kolaborasi dengan mahasiswa lain mampu memprediksi penyesuaian sosial secara positif. Akan tetapi, jumlah teman di LINE yang berasal dari kampus yang sama tidak memberikan kontribusi yang signifikan. Temuan-temuan dalam penelitian ini memberikan tambahan bukti tentang dampak SNS, terutama LINE, terhadap penyesuaian sosial mahasiswa tahun pertama di kampusnya. Namun demikian, penting untuk disadari bahwa SNS akan memberikan dampak positif jika mahasiswa mampu menjalin pertemanan yang nyata melalui LINE serta menggunakannya untuk kegiatan kolaboratif.
\end{abstract}

Kata kunci: mahasiswa; media sosial; penggunaan SNS; penyesuaian terhadap kampus; penyesuaian sosial

\section{Introduction}

Along with the rapid rise of the number of students enrolling into university, including in Indonesia (Kementerian Riset, Teknologi, dan Pendidikan Tinggi, 2018), the necessity and interest to understand the first-year college students, or freshmen, is increasing (Roser \& Ortiz-Ospina, 2016). Among the reasons is because the first-year students must accomplish many responsibilities and challenges that may become stressors affecting their quality of life (Christyanti, Mustami'ah, \& Sulistiani, 2012). The responsibilities are different from the ones they face at high school, due to the new environment they entering, from academic obligations to non-academic duties (Bowman, 2010). Consequently, first-year students need to adapt or adjust successfully.

The freshmen must go through a process called social adjustment. Social adjustment is students' ability to adjust to their new social college life (Baker \& Siryk, 1984, 1986). It is one of four 
aspects that construct college adjustment proposed by Baker and Siryk $(1984,1986)$. Social adjustment includes several elements: students' participation in the general college activity, involvement as the relation with others in the college, and satisfaction with social college life. Social adjustment is as crucial as, if not more important than, academic adjustment (Enochs \& Rolland, 2006; Estiane, 2015; Gerdes \& Mallinckrodt, 1994). It is one of the most critical activities emerging adults undertake and one that can predict their success in college and beyond (Baker \& Siryk, 1986; Gray et al., 2013).

Social adjustment is vital for the first-year students because many of the activities and responsibilities that they must face involve interactions with other people in the university. They need to socialize with peers or to build good relationships with their colleagues, lecturers, and the college institution itself. Moreover, for many, college life means living separately from their families for the first time (Eisenberg, Cumberland, Guthrie, Murphy, \& Shepard, 2005; Gray et al., 2013). They leave their families and childhood friends when they enter the new social environment of college. This situation forces them to live independently, increase their autonomy, and adjust socially (Bowman, 2010; Gray et al., 2013). Students who have difficulty adjusting socially to college are more likely to suffer loneliness, anxiety, and depression (Mounts, Valentiner, Anderson, \& Bowsel, 2006).

In this global era, however, the definition and methods of social interaction are changing. Access to interactions with others is shifting toward becoming unlimited. One can interact and build a relationship with an unfamiliar person located miles away with the help of social media. Social Networking Service (SNS) is one of the social media forms (Kaplan \& Haenlein, 2010) that can be used to do that. SNS is a web-based service that enables individuals to build up their profile, to see other users share their information, and to interact with other people in the system (Boyd \& Ellison, 2007).

SNS has been said to help facilitate college students' social adjustment (DeAndrea, Ellison, LaRose, Steinfield, \& Fiore, 2012; Gray et al., 2013). DeAndrea et al. (2012) found that SNS has a positive correlation with college adjustment. When students have an SNS account and use it to interact with their new friends in college, their college adjustment is better. In line with it, Gray et al. (2013) had shown that SNS use supports social adjustment for firstyear students. However, the knowledge of whether SNS has a positive impact on college students' social adjustment has not yet firmly established.

In contrast with the studies mentioned previously, Junco's (2011) study found that the use of SNS did not impact social relationships of college students. Additionally, Junco stated that there was no guarantee that if students had interactions with (C) 2020 Jurnal Psikologi Sosial their friends through SNS, they would also have faceto-face interactions. College students get more benefit from face-to-face interactions, as those who have such relationship show good academic outcomes and psychosocial engagement as the result of social adjustment (Pascarella \& Terenzini, 2005).

Therefore, this study tried to investigate the influence of SNS on college students' social adjustment, mainly because of the inconsistent results of previous research. Besides that, conducting this research in Indonesia is also valuable because as the fourth most populous country in the world (United Nations, 2017), Indonesia has a significant number of SNS users. Among the 132.7 million internet users in Indonesia, 95\% are SNS users (Statista Research Department, 2018). The number of SNS user in Indonesia is up to 81 million people (Statista Research Department, 2019). As a part of the new generation of first-year college students, Indonesian college students are also expected to utilize SNS in interacting and communicating with their social networks, including their new friends at the university.

Moreover, previous studies in Indonesia (Estiane, 2015; Sasmita \& Rustika, 2015) have mentioned that social relationship with peers has a significant contribution to college students' social adjustment. However, none of those studies have yet examined the connection between social ties facilitated by SNS use and social adaptation.

This research also aimed to verify the results of Gray et al. (2013) in their study about the effect of SNS use on social adjustment, by considering the different trend of SNS use in Indonesia. Gray et al. (2013) examined Facebook use as it was the most frequently used SNS in the US. However, despite the popularity of Facebook, LINE has also become a popular SNS in Indonesia. Notably, among the youth, the numbers of LINE users has reached almost 90 million users, with $41 \%$ of them were $18-22$ years old (Nistanto, 2016). By 2017, data has shown that the number of LINE users has increased to 171 million users (Ayuningtyas, 2017). Therefore, instead of Facebook, this study used LINE as the SNS measured. This study wanted to examine whether the usage of LINE as SNS significantly influenced the social adjustment of first-year college students. As a replication of the previous research conducted by Gray et al. (2013), this study defines SNS use accordingly. SNS use involves the number of SNS friends that come from the same college, the number of SNS friends considered as actual friends, and the propensity to use SNS for positive collaboration. The definition and measurement of social adjustment in this study were also the same as in Gray et al.'s study (2013), which was the definition and measurement scale developed by Baker and Siryk $(1984,1989)$.

Based on that, this study tested the following three hypotheses: 
(1) The number of $L I N E$ friends from the same campus (college) positively predicts the social adjustment of first-year students.

(2) The number of LINE friends considered actual friends positively predicts the social adjustment of first-year students.

(3) The propensity to use LINE for collaboration activity positively predicts the social adjustment of first-year students.

\section{Methods \\ Participants}

In total, 130 first-year college students were willing and fit the criteria completed the Google form version of the questionnaire. However, due to missing data (incomplete answers), the analysis only used 120 responses. The majority of participants were female (77.5\%). Their age ranged from 17 to 20 years old, with the mean was 18.71 years old $(S D=0.627)$. All of the participants came from public universities from several cities in Indonesia, including Jakarta, Depok, and Makassar. Majority of participants were Psychology major (52\%). Other participants came from various majors, which were Natural Science (12\%), Engineering (8\%), Medicine (8\%), Nursing (8\%), Economic (4\%), and Cultural Science (4\%).

\section{Design}

This study used a correlational, non-experimental study because it wanted to test the relationship among variables investigated, the way it happens in the real-life situation.

\section{Instruments}

There were two main instruments used in this study, which are the social adjustment scale and the LINE-usage measurement.

Social Adjustment Subscale. We measured social adjustment from the Indonesian adaptation of Baker and Siryk's (1989) Student Adjustment to College Questionnaire (SACQ) (Rifameutia \& Malay, 2016). There were 17 items with a seven-point Likert scale ( 1 = very unlikely to 7 = very likely). Rifameutia and Malay (2016) stated that the Indonesian adaptation of SACQ, especially the social adjustment subscale, had a high-reliability index (Cronbach's $\alpha=0.828$ ). The items in the subscale also have moderate correlation scores to total items (rit), ranged from $0.324-0.639$. In this study, the subscale also showed a high-reliability index (Cronbach's $\alpha=$ 0.880).

LINE Usage Measure. Meanwhile, to measure LINE usage, we used the Indonesian translation version of Facebook-use scale as applied in Gray et al. (2013). However, we replaced "Facebook" with "LINE" in all items. There were nine items in this instrument. The first item was question was about college friends in LINE. College friends in LINE defined as the number of LINE friends who attended the same college. It was measured by the open question, "Approximately how many of your total LINE friends attend the same college as you?". The second item was question was about actual friends in LINE. Actual friends in LINE defined as people on the LINE friends list perceived as real friends in daily life. An open question "Approximately how many of your total LINE friends do you consider actual friends?" measured this. Lastly, there were seven items to measure the propensity to use LINE for collaborative activity. These items used a five-point Likert scale ( 1 = never to 5 = always). Gray et al. (2013) created them to capture the expected probability of students using LINE to coordinate online or offline academic collaboration. One example of the items was, "I use LINE to arrange meetings for group projects." The scale to measure the propensity to use LINE for collaborative activity had a high-reliability index (Cronbach's $\alpha=$ 0.878). The correlation scores of each item to total items (rit) range from $0.317-0.784$.

\section{Procedure}

First of all, we asked permissions to use the measurement instruments chosen to be used in this study. We then created an online version of our questionnaire using a Google form application. The online survey consisted of the social adjustment measurement instrument, the LINE usage measurement instrument, and several questions on demographic data of this study's participants. Among the demographic data, questions were the participants' age, gender, university status, and study major.

After the measurement instruments preparation, we collected the data. Applying incidental sampling, we recruited as many firstyear college students who use LINE daily as possible through SNS and e-mail. Participants were selected based on practicality and availability of access, as the request letter and the link to the questionnaire was shared freely on SNS and e-mail. The privacy protection and description of the research were explained in the request letter. In addition to that, before responding to any item in the questionnaire, each participant was asked for their consent.

Once we had finished collecting data, we checked on the data and excluded all incomplete or error data (such as vague answer in the questions about the number of friends). Therefore, from 130 participants who completed the questionnaire, only data from 120 participants used in the statistical analysis. We omitted 10 data because the participants did not answer whole questions or they were not the freshmen. 


\section{Strategy of analysis}

The data were analysed using SPSS for Windows Version 22 as a statistical analysis tool. Descriptive statistics analysis was conducted to examine the demographic data and find the means of the variables. Pearson Correlation and Linear Regression analysis were carried out to test the relationships among variables.

\section{Results}

Descriptive statistics analysis showed that, on average, participants' social adjustment was above average $(M=4.803, S D=0.863)$. The average number of friends in LINE came from the same college $(M=149.09, S D=117.517)$ was higher than the number of LINE friends' participants considered as their actual friends $(M$ $=106.68, S D=129.363$ ). Both umbers had a wide range of score variation. As for the propensity to use LINE for collaborative activity, the participants had a high (above average) inclination $(M=4.077, S D=0.709)$. Table 1 shows the details.

Table 1 also displayed the correlation among all variables measured. Social adjustment was significantly related to two components of LINE usage. Those were the number of actual friends in LINE $(\mathrm{r}=0.192, \mathrm{p}<0.05)$ and the propensity to use LINE for collaborative activity $(\mathrm{r}=0.296, \mathrm{p}<0.01)$. Meanwhile, the number of college friends in LINE and social adjustment were not correlated significantly $(r=0.147$, $\mathrm{p}>0.05$ ). It means that one of this study's hypothesis could not be accepted. Because the number of LINE friends from the same college had no significant relationship with the first-year students' social adjustment, the first hypothesis was automatically could not be accepted. The number of LINE friends from the same college does not positively predict the social adjustment of first-year students.

Further statistical analysis with linear regression only involved two independent variables, namely the number of actual friends in LINE and the propensity to use LINE for collaborative activity, in predicting social adjustment of the first-year students. The results are displayed in Table 2.

The number of LINE friends considered actual friends by college students contributed significantly to their social adjustment scores $(b=$ $0.001, t(118)=2.125, p=0.036)$. The number of actual friends in LINE explained about $3.7 \%$ of the variance in social adjustment $\left(\mathrm{R}^{2}=0.037\right.$, $F(1,118)=4.514, p=0.036)$. Any changes in the number of friends in LINE a college student considered actual friends would increase social adjustment by 0.001 units while all other variables were constant. This result confirmed the second hypothesis, namely, that the number of LINE friends considered actual friends positively predicts first-year students' social adjustment.

Table 1.

Descriptive Statistics and Correlation between Social Adjustment and LINE Usage

\begin{tabular}{|c|c|c|c|c|c|c|}
\hline \multirow[t]{2}{*}{ Variables } & \multirow[t]{2}{*}{ M } & \multirow[t]{2}{*}{ SD } & \multicolumn{4}{|c|}{$\mathrm{R}$} \\
\hline & & & 1 & 2 & 3 & 4 \\
\hline Social Adjustment (1) & 4.803 & .863 & - & & & \\
\hline $\begin{array}{l}\text { Number of College Friends in } \\
\text { LINE (2) }\end{array}$ & 149.09 & 117.517 & $\begin{array}{c}0.147 \\
(p=0.108)\end{array}$ & - & & \\
\hline $\begin{array}{l}\text { Number of Actual Friends in } \\
\text { LINE (3) }\end{array}$ & 106.68 & 129.363 & $\begin{array}{c}0.192^{*} \\
(p=0.036)\end{array}$ & $\begin{array}{c}0.412^{*} \\
(p=.000)\end{array}$ & - & \\
\hline Collaborative Activity in LINE (4) & 4.077 & .709 & $\begin{array}{c}0.296^{*} \\
(\mathrm{p}=0.001)\end{array}$ & $\begin{array}{c}0.013 \\
(\mathrm{p}=0.892)\end{array}$ & $\begin{array}{c}0.162 \\
(\mathrm{p}=0.077)\end{array}$ & - \\
\hline
\end{tabular}

Linear regression analysis also showed that the propensity to use LINE for collaboration activity significantly accounted for $8.8 \%$ of the variance in social adjustment $\left(\mathrm{R}^{2}=0.088\right.$, $F(1,118)=11.337, p=0.001)$. Every unit change in the tendency of college students to use LINE for collaboration increased their social adjustment by 0.361 units, as long as other variables were constant $(b=0.361, t(118)=3.367, p=0.001)$. Therefore, the third hypothesis, the propensity to (c) 2020 Jurnal Psikologi Sosial use LINE for collaboration activity positively predicts the social adjustment of first-year students, was supported.

Simultaneously, the number of actual friends in LINE and propensity to use LINE for collaborative activity contributed significantly to students' social adjustment. Altogether, they could explain about $10.9 \%$ of the variance in the social adjustment $\left(R^{2}=0.109, F(2,117)=7.151, p\right.$ $=0.001$ ). 
Table 2.

Linear Regression Analysis Result

\begin{tabular}{lccccc}
\hline \multirow{2}{*}{ Variables } & \multicolumn{4}{c}{ Social Adjustment } \\
\cline { 2 - 6 } & $R^{2}$ & $b$ & $F$ & $t$ & $p$ \\
\hline Number of Actual Friends in LINE & 0.037 & 0.001 & 4.514 & 2.125 & 0.036 \\
Collaborative Activity in LINE & 0.088 & 0.361 & 11.337 & 3.367 & 0.001 \\
& & & & &
\end{tabular}

\section{Discussion}

We found that the number of college friends in LINE social media did not predict the social adjustment of first-year students. This result is different from the previous finding from Gray et al. (2013), which found that the number of college friends on Facebook positively contributed to changes in social adjustment. The difference may be explained using the results of Junco's (2011) study. According to Junco, connecting through SNS does not guarantee that college students interact face to face. If face-to-face interaction does not occur, the adjustment in social life is not affected. Face-to-face communication is one of the factors that influence social adjustment (Gray et al., 2013). Also, there is the possibility that even though students make friends with each other in LINE, they do not interact in any meaningful way.

This result could also be explained by attributing it to the finding from Yang and Brown (2015). Their study supported the idea that different type of SNS use would have a different effect on college adjustment. While using SNS to communicate with on-campus friends would have a positive relationship with college adjustment, communication with off-campus friends via SNS had no significant correlation. In line with the previous explanation, Yang and Brown (2015) highlighted that it is not the number of college friends that matter. Instead, the communication that happens between the student and his or her college friends that has an impact. So, even though a student has a lot of LINE friends coming from the same college, their friendship status would not influence their social adjustment when there is no proper interaction.

Based on this assumption, future research could use a different measurement to investigate SNS usage. For example, rather than asking the number of LINE friends from the same college, it may be better to ask the number of college friends in LINE who have ever been involved in personal interactions with the participant.

The other outcome of this study is that the number of LINE friends considered actual friends positively predicted social adjustment. Again, this is contradictory with the result of the previous research conducted by Gray et al. (2013). However, this result serves a supportive finding for their conclusion of the relationship between social capital and social adjustment. In the study of
Ellison, Steinfield, and Lampe (2007; 2011), they suggested that the number of "actual friends" on SNS is a predictor of social capital. Ellison et al. (2011) explained that having a higher number of actual friends correlated with students perceiving themselves as having a higher level of social capital. Also, they found that there is a strong association between SNS use and social capital. Bourdieu and Wacquant (1992) define social capital as the sum of the resources that accumulated to an individual or a group as a result of keeping a stable network relationship of mutual acquaintance and recognition, whether the resources are actual or virtual. In this study, the number of real friends in LINE owned by students could fall into the virtual category of resources. These previous findings explained how the number of actual friends on LINE could be related to social adjustment.

The relation between the number of actual friends in LINE with social adjustment could also exist through the mediation of social support. Social support is the social resources that individuals view to be available or offered to them when they need it (Estiane, 2015; Friedlander et al., 2007; Sasmita \& Rustika, 2015). The previous study shows that one of the factors predicting college students' adjustment is social support (Friedlander, Reid, Shupak, \& Cribbie, 2007). The same result has also been proven in the context of Indonesia college students (Estiane, 2015; Sasmita \& Rustika, 2015). According to these studies, social support from friends or peers influences freshmen' social adjustment positively. With regards to this study, LINE friends considered as the actual friends have a higher possibility to be perceived as social support for the freshmen than other friends they have through LINE. The more student perceived the availability of social support, the better their social adjustment would be. Therefore, a higher number of friends seen as an actual friend in LINE would predict better social adjustment.

The third result of this study is that collaborative activity in LINE was able to predict first-year college students' social adjustment. This result is quite different from the outcome of Gray et al. (2013), which stated that there was no direct correlation between the two variables. According to them, to be related, the two variables need bonding social capital as the 
mediator variable. However, the result is consistent with the outcome of the research conducted by Yang and Brown (2015). They proved that using SNS to communicate with oncampus friends would have a positive relationship with college adjustment. When students using LINE to collaborate with their friends in college, they would, of course, communicate with each other. Therefore, collaborative activity in LINE would contribute positively to students' social adjustment.

Moreover, according to previous research (Lampe, Wohn, Vitak, Ellison, \& Wash, 2011), using SNS to collaborate with other friends may help them adjust to college. It is because such activities (e.g., talking about homework or the learning process in class) provide opportunities to engage in focused and sustained interaction, to develop friendships, and to exchange social support. By planning collaborative activities in real life using the help of LINE as media, college students can also improve their skills in communicating, socializing, and working together in teams. Furthermore, recent research shows that connecting with other students online is an essential aspect of the socialization process in college (Heiberger \& Harper, 2008). These reasons explain why the propensity to use LINE for collaborative activities contributed to students' social adjustment.

As students' collaborative activities within LINE usually relates to homework or group projects, the propensity to use LINE for these could affect not only students' social adjustment but also their academic adjustment. Baker and Siryk (1984, 1989) proposed that college adjustment consists of another three aspects beyond social adjustment, which are as follows: academic adjustment, emotional adjustment, and institutional adjustment. Therefore, future studies could investigate the effect SNS use, especially LINE use for collaborative activity, on first-year students' academic adjustment or college adjustment in general.

Overall, this study showed different results compared to the previous similar study (Gray et al., 2013). These differences may be subject to the different characteristics of both populations. Some college students live independently during their college years. However, unlike in the USA, it is not uncommon for Indonesian first-year students to still live with their parents. This situation could give Indonesian first-year students more options for the resources of social capital and social support, not only from the LINE friends who attend the same college. On the other hand, the geographic condition of Indonesia may make it more difficult for a student who lives far away from their hometown to communicate with their close friends. In this case, SNS may help (c) 2020 Jurnal Psikologi Sosial them to be able to receive social support even from people who live far away.

Moreover, research on social media in Indonesia (Watie, 2011) suggested that for many people, online communication gives people more convenient access to form a close relationship. Through online interaction, each party involved tending to be more open and honest. This type of communication also considered easier, cheaper, and limitless as it knows no limitation in time and place. Therefore, being able to communicate with people regarded as real friends through SNS may help Indonesian students to adjust socially in their college. Asides from reason already mentioned, different nature of friendship in Indonesia and USA (French, Bae, Pidada, \& Lee, 2006) could also explain the result of this study. While students in the USA tend to limit their social contact, Indonesia students showed extensive social connections with others. However, they only have limited intimate interaction with specific individuals. This characteristic explains why, in this study, the number of college friends in LINE did not have a significant correlation with social adjustment, while the number of actual friends did. Despite many contacts students have with their college friends through LINE, their interaction could be only a surface interaction. Therefore, only when they use LINE for collaborative activities, it will have a significant relationship with their adjustment.

Lastly, even though two of the three predictor variables in this research have a significant impact, the contribution altogether was not high. Previous studies, including ones in Indonesian context, showed that first-year college students' adjustment could also be explained by their internal factors, such as personality (Ying \& Han, 2006; Hirai et al., 2015), self-efficacy (Chemers, Hu, \& Garcia, 2001; Irfan \& Suprapti, 2014; Majer, 2009; Wijaya, 2012), and gender (Enoch \& Rolland, 2006). The contribution of external factors, such as parental factors (Yazedjian, Toews, \& Navarro, 2009; Wijaya, 2012) or place of living (Al-Qaisy, 2010; Enoch \& Rolland, 2006) to college adjustment were also confirmed. Further research should consider whether to include or to control these variables when measuring the strength of the effect of SNS use on first-year college students' adjustment.

Nonetheless, this research adds to a growing corpus of studies debunking media reports that link the use of social media, like Facebook, to adverse academic outcomes such as lower grades. This study result may be unable to establish a firm causal relationship between variables as the design of this study is nonexperimental. However, the data presented suggest that specific uses of SNS (to collaborate 
positively) would help students feel more connected to the social life in college. This condition may subsequently increase the likelihood that they will persist beyond their first year. This effect of SNS is especially crucial for first-generation and minority students, who are historically less likely to attend (and finish) college. This research complements other works that SNS use can have meaningful outcomes. Contrary to some popular depictions, SNS could be more than merely a forum for sharing breakfast choices and party photographs. It has the potential to serve as a medium for meaningful support at a transition time in college students' lives.

\section{Conclusion}

In this study, the number of LINE friends from the same college did not predict the social adjustment of first-year college students. Meanwhile, the number of LINE friends considered actual friends and the propensity to use LINE for collaborative activity positively influenced the freshmen's social adjustment. These results give more evidence on the impact of SNS has on students' social adjustment in their college. Especially in the Indonesian context, the quality (the depth) of the friendship with SNS friends and the type of activity conducted through the SNS is more substantial than the mere number of the person from the same college registered as friends in the SNS.

\section{Limitations and Suggestions.}

There are several limitations to this study. Firstly, as mentioned in the discussion section, the control of other variables that influence college students' adjustment in this study was very minimal. Therefore, further research should consider whether to include or to control these variables when measuring the strength of the effect of SNS use on first-year college students' adjustment. The second limitation is the number of participants in this study. As discussed in the beginning, university enrolment in Indonesia has been increasing in recent years. Collecting data from a more significant number of participants, who come from more various universities in Indonesia will provide more representative results on Indonesian college students' adjustment.

Lastly, as demonstrated in the study by Yang and Brown (2015), most studies measuring SNS use are usually focused on one or limited aspect. Frequently, scholars assessed SNS use in terms of amount or frequency. This study also offered no significant difference. Despite the effort to measure one kind of activity (collaborative activity) done by students through SNS, we only measured the number of friends in LINE to assess LINE use. Therefore, there is a need to measure
SNS use with a more comprehensive definition in future research. It would make our understanding of how SNS use could affect students' social adjustment to be even more precise. Moreover, as explained in the discussion section, the measurement of friendship quality in the SNS seems to play a more impact than the quantity.

\section{References}

Al-Qaisy, L.M. (2010). Adjustment of college freshmen: the importance of gender and the place of residence. International Journal of Psychological Studies, 2(1), 142$150 . \quad$ Retrieved from http://www.ccsenet.org/ijps.

Ayuningtyas, R. (2017, June 20). Line kantongi 171 juta pengguna aktif bulanan (Line bags 171 million active users monthly). Retrieved from https://www.liputan6.com/tekno/read/2 997411/line-kantongi-171-jutapengguna-aktif-bulanan.

Baker, R. W., \& Siryk, B. (1984). Measuring adjustment to college. Journal of Counseling Psychology, 31(2), 179-189. http://dx.doi.org/10.1037/00220167.31.2.179.

Baker, R. W., \& Siryk, B. (1986). Exploratory intervention with a scale measuring adjustment to college. Journal of Counseling Psychology, 33(1), 31-38. http://dx.doi.org/10.1037/00220167.33.1.31.

Baker, R. W., \& Siryk, B. (1989). Student adaptation to college questionnaire: Manual. Western Psychological Services.

Bourdieu, P., \& Wacquant, L. J. (1992). An invitation to reflexive sociology. University of Chicago Press.

Bowman, N.A. (2010). The development of psychological well-being among first-year college students. Journal of College Students Department, 51(2), 180-200. Retrieved from https://muse.jhu.edu.

Boyd, D. M., \& Ellison, N. B. (2007). Social network sites: Definition, history, and scholarship. Journal of computer-mediated Communication, 13(1), 210-230. doi:10.1111/j.1083-6101.2007.00393.x

Chemers, M.M., Hu, L., \& Garcia, B.F. (2001). Academic self-efficacy and first-year college student performance and adjustment. Journal of Educational Psychology, 93(1), 55-64. http://dx.doi.org/10.1037//00220663.93.1.55.

Christyanti, D., Mustami'ah, D., \& Sulistiani, W. (2012). Hubungan antara penyesuaian diri terhadap tuntutan akademik dengan kecenderungan stres pada mahasiswa 
Fakultas Kedokteran Universitas Hang Tuah Surabaya. Jurnal Insan Media Psikologi, 12(3), 153-159.

DeAndrea, D. C., Ellison, N. B., LaRose, R., Steinfield, C., \& Fiore, A. (2012). Serious social media: On the use of social media for improving students' adjustment to college. The Internet and higher education, 15(1), 15-23. https://doi.org/10.1016/j.iheduc.2011.05 .009 .

Eisenberg, N., Cumberland, A., Guthrie, I.K., Murphy, B.C., \& Shepard, S.A. (2005). Age changes in prosocial responding and moral reasoning in adolescence and early adulthood. Journal of Research on Adolescence, 15(3), 235260. https://doi.org/10.1111/j.15327795.2005.00095.x.

Ellison, N.B., Steinfield, C., \& Lampe, C. (2007). The Benefits of Facebook "Friends:" Social Capital and College Students' Use of Online Social Network Sites. Journal of ComputerMediated Communication, 12 (4), 11431168. https://doi.org/10.1111/j.10836101.2007.00367.x.

Ellison, N., Steinfield, C., \& Lampe, C. (2011). Connection strategies: social capital implications of Facebook-enabled communication practices. New Media \& Society, 13 (6), 873-892. https://doi.org/10.1177\%2F1461444810 385389.

Enochs, W. K., \& Roland, C. B. (2006). Social adjustment of college freshmen: The importance of gender and living environment. College Student Journal, 40(1), 63-74.

Estiane, U. (2015). Pengaruh dukungan sosial sahabat terhadap penyesuaian sosial mahasiswa baru di lingkungan perguruan tinggi. Jurnal Psikologi Klinis dan Kesehatan Mental, 4(1), 29-40.

French, D. C., Bae, A., Pidada, S., \& Lee, O. (2006). Friendships of Indonesian, South Korean, and US college students. Personal Relationships, 13(1), 69-81. https://doi.org/10.1111/j.14756811.2006.00105.X

Friedlander, L. J., Reid, G. J., Shupak, N., \& Cribbie, R. (2007). Social support, self-esteem, and stress as predictors of adjustment to university among first-year undergraduates. Journal of college student development, 48(3), 259-274. https://doi.org/10.1353/csd.2007.0024.

Gerdes, H., \& Mallinckrodt, B. (1994). Emotional, social, and academic adjustment of college students: a longitudinal study of retention. Journal of Counseling \& Development, 72, (C) 2020 Jurnal Psikologi Sosial
281-288. https://doi.org/10.1002/j.15566676.1994.tb00935.x.

Gray, R., Vitak, J., Easton, E.W., \& Ellison, N.B. (2013). Examining social adjustment to college in the age of social media: factors influencing successful transitions and persistence. Computers \& Education, 67, 193-207.

https://doi.org/10.1016/j.compedu.2013. 02.021 .

Heiberger, G., \& Harper, R. (2008). Have you Facebooked Astin lately? Using technology to increase student involvement. New directions for student services, 2008(124), 19-35. https://doi.org/10.1002/ss.293.

Hirai, R., Frazier, P., \& Syed, M. (2015). Psychological and sociocultural adjustment of first-year international students: trajectories and predictors. Journal of Counseling Psychology, 62(3), 438-452. http://doi.org/10.1037/cou0000085.

Junco, R. (2011). The relationship between frequency of Facebook use, participation in Facebook activities, and student engagement. Computers \& Education, 58 (1), 162-171. http://doi.org/10.1016/j.compedu.2011. 08.004 .

Kaplan, A. M., \& Haenlein, M. (2010). Users of the world, unite! The challenges and opportunities of Social Media. Business horizons, 53(1), 59-68. doi:10.1016/j.bushor.2009.09.003

Kementrian Riset, Teknologi, dan Pendidikan Tinggi RI (Kemenristekdikti). (2018). Statistik pendidikan tinggi 2018: Overview gambaran umum. Retrieved from https://ristekdikti.go.id/epustaka/bukustatistik-pendidikan-tinggi-2018/

Lampe, C., Wohn, D.Y., Vitak, J., Ellison, N., \& Wash, R. (2011). Student use of Facebook for organizing collaborative classroom activities. International Journal of Computer-supported Collaborative Learning, 6(3), 329-347. https://doi.org/10.1007/s11412-0119115-y.

Majer, M. (2009). Self-efficacy and academic success among ethnically diverse firstgeneration community college students. Journal of Diversity in Higher Education, $2(4)$, 243-250. http://dx.doi.org/10.1037/a0017852.

Mounts, N. S., Valentiner, D. P., Anderson, K. L., \& Boswell, M. K. (2006). Shyness, sociability, and parental support for the college transition: Relation to adolescents' adjustment. Journal of Youth and Adolescence, 35(1), 68-77. 
https://doi.org/10.1007/s10964-0059002-9.

Nistanto, R.K. (2016, September 03). Di Indonesia Jumlah Pengguna Line Pepet Facebook (In Indonesia, the number of LINE user has almost surpassed Facebook). Retrieved from

http://tekno.kompas.com/read/2016/09

/03/ 09490637/

di.indonesia.jumlah.pengguna.line.pepet.f acebook.

Pascarella, E.T., \& Terenzini, P.T. (2005). How college affects students: $A$ third decade of research. San Francisco, CA: Jossey-Bass.

Rifameutia, T., \& Malay, E.D. (2016, February). First-Generation vs. second-generation college students: their academic selfefficacy and college adjustment. Proceeding: Enhancing Academic Collaboration through ASEA-UNINET Scientific Meeting. Bali, Indonesia: Udayana University.

Roser, M., \& Ortiz-Ospina, E. (2016, August 31). Global Rise of Education. Retrieved from https://ourworldindata.org/global-riseof-education.

Sasmita, I. A. G. H. D., \& Rustika, I. M. (2015). Peran efikasi diri dan dukungan sosial teman sebaya terhadap penyesuaian diri mahasiswa tahun pertama Program Studi Pendidikan Dokter Fakultas Kedokteran Universitas Udayana. Jurnal Psikologi Udayana, 2(2), 280-289.

Statista Research Department. (2018). Penetration of leading social networks in Indonesia as of $3^{\text {rd }}$ quarter 2017. Retrieved from

https://www.statista.com/statistics/284 437/indonesia-social-networkpenetration/.

Statista Research Department. (2019, February 20). Number of social network users in Indonesia from 2017 to 2023. Retrieved from

https://www.statista.com/statistics/247 938/number-of-social-network-users-inindonesia/

United Nations. (2017, June). World population prospects: The 2017 revision. Retrieved from https://esa.un.org/undp/wpp/ download/standard/population/.

Yang, C. C., \& Brown, B. B. (2015). Factors involved in associations between Facebook use and college adjustment: Social competence, perceived usefulness, and use patterns. Computers in Human Behavior, 46, 245-253. http://dx.doi.org/10.1016/i.chb.2015.01. $\underline{015}$.

Yazedjian, A., Toews, M. L., \& Navarro, A. (2009). Exploring parental factors, adjustment, and academic achievement among White and Hispanic college students. Journal of College Student Development, 50(4), 458467.

http://dx.doi.org/10.1353/csd.0.0080.

Ying, Y. W., \& Han, M. (2006). The contribution of personality, acculturative stressors, and social affiliation to adjustment: A longitudinal study of Taiwanese students in the United States. International Journal of Intercultural Relations, 30(5), 623-635. https://doi.org/10.1016/j.ijintrel.2006.02 .001

Watie, E.D.S. (2011). Komunikasi dan media social (Communications and social media). The Messenger, Vol.III(1), 69-75.

Wijaya, I. P. (2012). Efikasi diri akademik, dukungan sosial orangtua dan penyesuaian diri mahasiswa dalam perkuliahan. Persona: Jurnal Psikologi Indonesia, 1(1), 40-52. https://doi.org/10.30996/persona.v1i1.1 $\underline{4}$ 